Article

\title{
The Achievement of University Access: Conversion Factors, Capabilities and Choices
}

\author{
Melanie Walker \\ SARCHI Chair in Higher Education \& Human Development Research Programme, University of the Free State, \\ 9301 Bloemfontein, South Africa; E-Mail: walkermj@ufs.ac.za
}

Submitted: 12 June 2018 | Accepted: 7 September 2018 | Published: 10 January 2019

\begin{abstract}
In the light both of persistent inequality of education opportunities for low income families and a wide equality gap in South Africa, this article explores students' university access by applying Amartya Sen's capability approach to a South African case study. The article demonstrates empirically that access is more than an individual project, shaped both by objective conditions and subjective biographies, that is by general conversion factors and a person's social and personal options. Key conversion factors are material (income) and social (family, community, school, information), which produce an interlocking system of opportunity. Access thus requires more than formal opportunity to enable social mobility for all. The case study comprises qualitative interviews with diverse students in their first year at one university; illustrative narratives are selected to show different pathways, conversion factors and choices. Agency and self-efficacy emerge as especially important for making choices but also for constructing a higher education pathway where none exists for that person and her family. The article suggests that higher education has the potential to advance social mobility provided that it moves in the direction of expanding the capabilities of all students to have the choice of higher education.
\end{abstract}

\section{Keywords}

capability approach; fair access; South Africa; university

\section{Issue}

This article is part of the issue "Inequalities in Access to Higher Education: Methodological and Theoretical Issues", edited by Gaële Goastellec (University of Lausanne, Switzerland) and Jussi Välimaa (University of Jyväskylä, Finland).

(C) 2019 by the author; licensee Cogitatio (Lisbon, Portugal). This article is licensed under a Creative Commons Attribution 4.0 International License (CC BY).

\section{Introduction}

In South Africa it is matter of deep concern that almost 25 years after the first democratic elections, race, education, and labour market income are still key contributors to high levels of inequality. Poverty is high for a middle income country and mobility is low, while black South Africans consistently exhibit the highest poverty rates. The recent World Bank report (Sulla \& Zikhali, 2018) shows that with a Gini coefficient of 0.63 , South Africa is the most unequal country in the world for which reliable data is available, while the country is also tremendously unequal based on wealth distribution. A significant determinant of this inequality is inequality of opportunity, including to higher education, where despite high private returns, access remains limited especially from rural provinces which tend to be poorer overall. In the light of stubborn inequalities, fairness in access to university is of some concern: who goes to university, who benefits and whose social mobility is advanced are important questions in a country which is so economically polarized. Without access, social mobility cannot follow, nor can the wider public good of higher education be well served if only better-off students get into university.

Thus, we need to understand the conditions under which differently positioned students construct mobility pathways by first gaining access to university. Surprisingly, access is still under-researched in South Africa (see Walker, 2018), with most research focused on student experiences at university. This article therefore draws on a qualitative interview project to discuss access choices, where access is understood as having been achieved at 
the point when a student is able to register for her programme and pay the initial fee. The assumption is that access is more than an individual project, but rather intersectionally shaped both by objective conditions (such as economic conditions, government policy, structures of gender and race) and subjective biographies (such as hard work at school, or encouragement to succeed from a family member). The underlying concern is with equality of access conditions and choices for students from different backgrounds. In short, is access fair?

Internationally, Spiegler (2018) has usefully summed up key findings on inequality in education-these hold also for access. According to Spiegler, there are two wellestablished findings: 1) access to and achievements in education are shaped, but not over-determined, by social background; and 2) there are always examples of individuals who make it despite coming from lower social strata. This holds for South Africa where some students from low income backgrounds do make it into higher education and of course others do not, but this should be understood as an issue both of social conditions rather than only individual efforts and talents. The issue would be to change the former and encourage the latter. The article thus takes up the challenge of social background and individual effort, first sketching the South African context, then outlining key features of the capability approach as a framework for examining student well-being. These ideas are then applied to three illustrative narratives from a qualitative interview project on access, looking at students from different social class and schooling quality backgrounds to understand their individual pathways into higher education.

\section{A Context of High Poverty and Low Mobility}

As already noted, social mobility is low and poverty is high; but poverty also declines with rising levels of education and hence social mobility (Sulla \& Zikhali, 2018). A higher level of education of the household head and access to stable employment and income (which can be a major instrumental gain from getting a university degree) are key determinants for households to achieve economic stability. In 2015, $73.1 \%$ of the population living in households whose head did not have a formal education were classified poor, versus $2.6 \%$ of those living in households whose head had an education beyond upper secondary school. Similar patterns hold for individuals. In 2015, the median income for people in South Africa with a university degree was almost six times that for those without one (Makgetla, 2018). Importantly, only one in four South Africans can be considered securely middle class, whereas the other three are either poor or, even if in the emerging middle class, still face the risk of downward mobility if their circumstances change. It takes more than one generation to secure middle class status (Southall, 2016). Higher education for children from these families could make a significant difference in family class stability, while for poor families it may work to help lift the family out of poverty. This would be especially the case for black families where commitment to the welfare of the extended family remains strong.

Overall, opportunities are constrained by a dysfunctional public schooling system. Public schools are divided into five quintiles which are rough proxies for socioeconomic status. The lowest quintile (Q1) schools are the poorest, while Q5 are the formerly advantaged schools and the best performing. Q1 to Q3 schools do not charge fees, while Q4 and Q5 schools do, with Q5 schools charging the highest fees. The latter will tend to be located in well-off suburbs at some distance from low income black townships and hence requiring investment in travel costs. The majority of public schools are in Q1, Q2 and Q3 providing low quality education for some $75 \%$ of young people (Spaull, 2012), with the remaining 25\% attending fee-paying, good quality Q4 and Q5 public schools. For example, in the poorest $80 \%$ of schools, only $1 \%$ of learners in grade 8 will go on to pass grade 12 (the final year of school) and obtain a C symbol or higher (60\%) for Mathematics and Physical Science (the prerequisite for most mathematical or science degree programs at university). Approximately ten times as many students reach this level in the wealthiest $20 \%$ of schools. As a proportion, the number of Q5 students in Grade 8 that will go on to pass grade 12 with a university entrance pass is four times higher than that for Q1 students. A wealth index for school districts compiled by Van Broekhuizen, Van Der Berg and Hofmeyr (2016) confirms that university access is positively associated with the wealth index of the schools that learners attended. Spaull (2012) therefore characterizes South Africa as having two public schooling systems, suggesting considerable access obstacles for those students in low quality schools and expanded opportunities for those in good schools. Van Broekhuizen et al. (2016) report that in general learners from urbanized areas like Gauteng and the Western Cape have the highest university access rates, while rural areas have the lowest. In Free State province (where the students in this study originate) only some $21.8 \%$ of learners attain the necessary grades in the final year of school that will admit them to study for a degree at university, and of these, $70 \%$ go on to university, making students in the case study effectively 'best cases' of access. Most students choose to attend one of the two universities in the province, although the highest achieving students may prefer an elite university, such as the University of Cape Town.

Attending a good (Q5) school does not always correlate with coming from a better-off family as families may choose to make trade-offs in order to enable a child to gain better schooling. In a relatively fluid class structure like that of South Africa with its emerging black middle class, there is no neat correlation between social class, mobility and academic achievement, even though by and large emerging and established middle class children (black and white) in good schools will perform better. Race, parents' education, parents' occupation, and 
place of birth all influence available opportunities (Sulla \& Zikhali, 2018). Gender appears to be positive for girlsthrough schooling and university-excepting those from poor black families (Van Broekhuizen \& Spaull, 2017).

These contextual trends will influence (but not overdetermine) opportunity and choices at the micro level. To evaluate inclusion and justice, we also need to know about the actual experiences of students and their agency, their day-to-day realities in making decisions and getting into university or forming and sustaining their aspirations for social mobility. This is where a capability approach (Sen, 2009) informed understanding is valuable. As Sen (2009, p. 18) reminds us, 'justice cannot be indifferent to the lives that people can actually lead'.

\section{Capabilities}

The capability approach (Robeyns, 2017; Sen, 2009) enables us to think about higher education access in terms of expanding people's capabilities (also called 'freedoms') to access a university and programme of their choice. The actual exercise of capabilities to make choices would enable the person's options to 'function', that is, actual achievements like access. Converting a bundle of resources into capabilities and capabilities into 'functionings' is shaped by 'conversion factors', including structures of race and social class (see Figure 1). Thus, according to Robeyns' (2017), the capability approach points to the effect of: 1) (adequate) resources as the means to achieve (income, wealth, schooling, and so on); and 2) general conversion factors (structural constraints such as social norms, other people's behaviours, race and class, and so on) which shape each person's capability set, in this case to achieve access. Fair university access should then focus on the extent to which people have the same opportunities, with capabilities as the informational basis for interpersonal and comparative evaluations.

In this case study, conversion factors include the political situation, such as changes to government policy post 1994 to widen access by black (African) students. Indeed, the headcount number of black students continues to increase-from 640442 out of 938200 students in 2011 to 701482 out of 975837 in 2016 (Council on Higher Education [CHE], 2016, p. 3). The participation rate has increased slightly for African students from $14 \%$ to $16 \%$ but remains much higher for white students at $50 \%$ in 2016 (although falling from 57\% in 2011; CHE, 2016 , p. 6). Government policy also provides government loans and bursaries to students from very low income families, and from 2018 first time entering low income students have not had to pay university fees. Wider conversion factors include political factors such a policy of (limited) redistribution through social grants and pensions for the poor, but also the historical effects of racial disadvantage and the scarcity of available university places for those who qualify, which will affect differently positioned students unequally (Walker, 2018). On the other hand, gender may work as an advantage for most girls as noted above.

Southall (2016) argues that race and social class still define schools (and by implication achievements postschool) so that both working together would be a conversion factor, but also bearing in mind the fluidity of social class in South Africa and the potential impact of higher education on family mobility. Also important would be the family history of education and the quality of the school attended. Finally, urban infrastructure can also work as a conversion factor especially in the light of persistent apartheid patterns of spatial segregation. This determines the distance and cost involved to travel to school or university (further for the poor and black), the affordability of accessing a university which is far from one's home, and the lack of cheap and safe local, regional and national public transport in South Africa.

These general factors work out in the form of individual circumstances and options. For example, social class and race might work out for an individual student in a black parent who recognizes the crucial role schooling plays in class mobility and makes every possible effort and trade-off (the family goes without other goods so that school fees can be paid, or money is borrowed) to get a child into a good quality school rather than send her to a low quality neighbourhood school. Families and parents may constitute crucial preference formation mechanisms (what I take to be desirable and attainable for me) in positive or negative ways. At one extreme are the middle-class parents who engage actively with regard to their children's school choice, schooling and their extra-curricular activities. For students where there is no knowledge or experience of higher education in the family, it is the students who must be agents-of school choice, school subjects and choice of university. Schools constitute a further specific case of social institutions working out as individual options and access pathways. In some schools - primarily high fees Q5 schoolsadmission to university is more or less embedded in the life of the school and expected as the normal biography of most or all students. Students are provided with considerable information to navigate admissions and to choose careers, as well as a great deal of additional academic support. A low income black student who can get into such a school will have more and better information than if she had attended a township school. But a student from the poorest schools will have to make the most of her own talents and agency, often with at least some support, however limited, from a teacher.

Another way of thinking about the nexus of the person and general conversion factors is Nussbaum's (2000) notion of 'combined capabilities', that is 'internal capabilities' (such as having the aspiration to go to university), together with the external-social uptake conditions that effectively enable that person to exercise the capability as an achieved aspiration. The strength of the capability approach is that it combines both internal capabilitiesas in one's skills, attitudes, knowledge and information- 
with the options one has to act on them within one's social context and its constraints. Both aspects need to be the focus of our attention in education. Thus, general conversion factors work out as each person's specific conversion factors, shaping the combined capability set for that person.

No single conversion factor works on its own and intersecting general conversion factors shape but do not over-determine life chances in the face of agency, but it is nonetheless fair to say that material resources, especially access to income, is foundational to opportunities. We then have something that looks like this (Figure 1) to show the conversion points of resources (endowments) into capabilities and functionings.

A capability set is mobilized under conditions of possibility but is also shaped by the person's 'self-efficacy' (Bandura, 1994) which 'thickens' Sen's (2009) notion of agency as the pursuit of the goals one has reason to value. Bandura (1994) defines self-efficacy as people's beliefs about their ability to exercise influence over events that affect their lives. Thus, self-efficacy beliefs shape how people feel, think, motivate themselves and behave; a strong sense of self-efficacy can enhance human accomplishment and personal well-being. Low selfefficacy manifests in low aspirations and weak commitment to one's goals. We cannot assume that high efficacy necessarily correlates to being middle class in South Africa, nor that low self-efficacy applies to low income students. Indeed, the latter may be more likely to have a robust sense of self-efficacy, enabling them to overcome unfavourable circumstances to convert their schooling outcomes into a university place. When people overestimate their capabilities (university looks objectively like an impossibility, but the person aspires to go) this need not be seen in a negative light in that it en- ables aspirations beyond the person's immediate reach and fosters the effort needed to achieve such aspirations. The South African case is remarkable for the determination of low income students to create capability and choice pathways, to perceive choices which may not yet be in place, and to hold high aspirations. Selfefficacy may be significant in forming preferences which direct a student to choose and succeed in higher education and hence may be a foundational capability for access. Both agency and its driver of self-efficacy, however, must always be understood as happening under conversion conditions, they are not free-floating possibilities, as Figure 1 shows.

Self-efficacy may also contribute to overcoming what Sen (2009) calls 'adapted preferences', where choices may not always be in a person's best interests-for example, choosing a university programme which seems attainable even though it is not what the student wants to do, and even though another more suitable choice is also possible. Such choices might make it difficult to realize a capability which would otherwise be valued. People may also undervalue important capabilities because of their social circumstances. For example, if a community as a whole sees little point in education beyond grade 12 or even high achievement at school, a person may not value hard work or doing well and may not aspire to university, even though they have the basic ability. Or if her peers are high-achieving girls' intent on university, a student may adapt her preferences upwards. Such adapted preferences may emerge from gender, race, class or intersections of such structures and will begin forming rather early in life. Such preferences (and the corresponding choices will then be iterative through a person's (educational) life as she makes choices that reduce or expand her opportunity set.

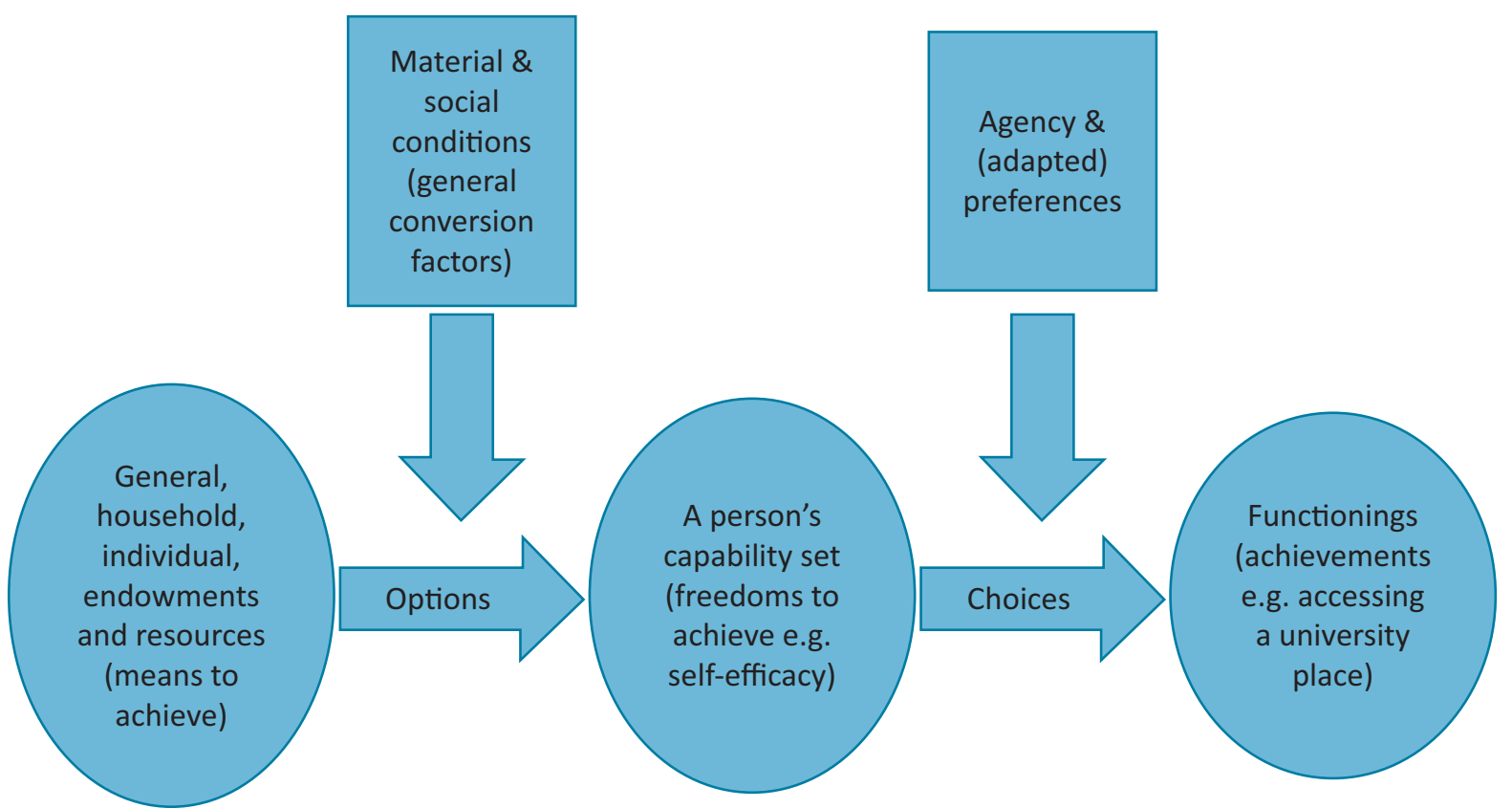

Figure 1. Adaptation of DeJaeghere and Baxter (2017, p. 70). 


\section{Identifying Capabilities through Interviews}

The UFS is a mid-ranking research and teaching university with a majority black student population and draws students from the Free State, but also the adjoining Eastern Cape and Kwa-Zulu Natal. To consider the combined capabilities of diverse students, in 201754 interviews with first year students at the University of the Free State (UFS) were conducted by the research team after which we divided up the writing of a one-page synopsis on each student. We are all researchers at the University but have no other relationship to any of the students interviewed. All students were given pseudonyms. We did not interview families but did interview six staff members with responsibilities for marketing the University to and at schools. This article focus focuses only on the students. In 2017, the UFS lacked school quintile data for around $25 \%$ of the undergraduate intake. Of those for whom they had information out of the total entry, $25.52 \%$ came from the best (Q5) schools and $10.42 \%$ from Q4 schools, also fee-paying but not as prestigious. The rest came from non-fee-paying schools often of low quality: $15.19 \%$ from Q3, 8.21\% from Q2 and $11.5 \%$ from Q1. This suggests reasonable access by students from non-fees schools and the possibility that the University is regarded as an attainable aspiration.

Some students were in the first year of the extended programme which allows admission with a lower score (made up from the subjects studied for grade 12) but adds an additional year of study to the degree. We contacted students at random via telephone, using a first-year list. We hoped for 60 participants but ended up with 54. Of the 54 students, 36 were female and 14 were white so that white students were over-represented in the sample according to the university's demographics. Across the school quintiles the majority came from Q5 (29) and Q4 (6) schools, with the remainder spread across Q1 to Q3. Only two students came from the very poorest (Q1) schools. 23 of the students had parents with no post grade 12 education. The rest had parents with a mix of post grade 12 diplomas and university degrees, meaning there was some educational history of study beyond grade 12 .

Individual interviews lasted around 45 minutes and were recorded and transcribed in full. In the interview students were asked to talk about their secondary school, their families and communities, the affordability of higher education for them, how they came to choose the UFS, their first experiences of university and their future aspirations. Analysis across the data set focused on 14 descriptive codes generated by the interviews: decisionmaking, critical moments, significant others, family, community, schooling, hard work, funding, friends, out of school, future plans, information, language and transport. From there, conceptual themes of choices, agency, conversion factors and capabilities were extrapolated.

While all the students in this study had made it to university, the terrain of choosing was uneven. To this end, I now focus on three narratives to show in more detail how conversion factors and agency pathways work out for diverse students, taking the example of three black girls to control for race and gender and across the spectrum of fee and non-fee schools. One student is from a Q5 school, one from a Q3 school and one from a Q1 school. The Q5 example is chosen both because interpersonal comparison and variation is important in the capability approach, but also to illustrate the earlier point about the fluidity of the emerging black middle class so that higher education is rather important to gaining but also to securing middle class status-as parents recognize (see Southall, 2016).

\subsection{Illustrative Narratives: Palesa, Aphiwe and Thabile}

Palesa's narrative is similar to that of other girls at Q5 schools whom we interviewed, although the black girls in general demonstrate a stronger sense of agency than the white girls who can rely on generational family histories of university and family wealth, making university an easy choice. For the black girls like Palesa from emerging middle class families, they have no inherited wealth but there is at least one parent who has been to university and has a professional and secure job. Her mother, a primary school teacher in the local township, places great store on education as the way to secure social mobility for the family and the individual. While her mother's job is secure it will not be especially well-paid and finding money for school fees was a struggle. Palesa lives with her mother (but during university terms she now lives on campus) and her younger sister in an urban black township and finds little community support there for her aspirations but a number of people in her extended family have gone to university or post-grade 12 colleges. Her father does not live with them and she did not mention him in the interview at all. Hard work is emphasised by her mother who believes that 'you live in your child's school bag'. She was determined that Palesa would go to a good high school, moving her from a Q4 primary school to the leading all-girls school in Bloemfontein, which advertises itself as offering 'access to opportunities'. Being in a leading Q5 school greatly helped Palesa gain access to higher education:

It would open doors for me and they would help rear me as an individual.... I showed potential if I can put it that way....[The school] just help[s] you to be proud of who you are.

Although the fees were high, her mother managed to find the money. The limits of township schools are clear to Palesa, even though 'they try by all means to prepare the children but there's only so much you can do with limited resources'. She is aware of the agency these students need to get to university: 'the children who are here are the children who took initiative'.

The school fostered Palesa's development in all kinds of ways-academic achievement, confidence, and involvement in activities. It 'was academically excellent' with a $100 \%$ grade 12 pass rate and $97 \%$ university en- 
trance passes. Teachers had very high expectations of students, so much so that 'it was exhausting'. Students had to attend extra maths classes in the evenings and maths camp in school holidays. In addition, Palesa also attended the Science Olympiad and the World Knowledge Olympiad. The school assisted in choosing subjects for grade 10, offering careers guidance and aptitude tests, although Palesa did not pay attention to the latter and chose 'subjects I knew I would be able to do'. Her mother also assisted by encouraging her to keep 'her options open' in her subject choices. Subjects like an African language (widely offered in Q1 to Q3 schools) were not offered unless you were 'failing'. In the end Palesa chose business studies, physical science, maths and drama. Her mother wanted her to do maths and science and 'did not quite believe' in business studies; she was concerned that Palesa should not limit herself. Palesa then decided to change from business to history but without telling her mother until Palesa could show her mother her good marks. History, Palesa felt, would equip her better for university. Overall, Palesa commented on the volume of work at school, on being expected to work independently, and learning to deal with a large volume of theory, so much so that 'my friends from other schools were amazed at the number of books I carried'.

Palesa had 'always' planned to go to university; it 'was expected' and in grade 12 decided on law. She had discussed this with her mother but was determined to make her own decision because '[she felt] like each child should have a choice of what they want to do'. Extended family members (aunts, uncles, grandmothers) were involved in so far as they influenced her mother, but Palesa 'was not having it'. While she accepts that 'your parents should guide you' and that some career choices ('such as fashion design') should be ruled out, she wanted to make up her own mind. But her mother did support Palesa's eventual choice to study law. In making up her mind, Palesa had access to wide information about higher education from her family and via her school. A number of leading universities had visited her school, including the elite universities of Stellenbosch and Cape Town but also the local universities (UFS and Central University of Technology [CUT]). She had also attended (and could afford to travel there) UFS Open Days in both grade 11 and 12. Initially Palesa did not plan to go to UFS, preferring UCT: 'Cape Town was the goal for me....It's the best university in South Africa'. But she did not think she would have high enough marks for Law there. UCT offered her a place in Social Science but she had also applied for Law at UFS and was offered a place there, just making the lower academic requirements. By April of her first year Palesa had heard that she had full funding from the Free State provincial government, although this was conditional on her working for them for four years after graduating. She would prefer to join a leading law firm so, 'it [was] not ideal but it's what you have to do'. Still, her path to university was relatively straightforward and well supported by her family and her school. Even though her academic achievement did not allow her first choice of university she did end up in the programme of choice (law). Race and gender together worked to her advantage in enabling funding from the provincial government. Without it her mother would have struggled to pay the full costs of university.

By and large, across Q1-Q3 schools, students demonstrate significant agency and determination in forging a pathway that does not yet exist in the family but that will get them to university. Thabile attended a Q3 school. Her parents were not involved in the choice of school-she made the decision because 'the school had a good image'. Indeed, her mother showed little interest, saying: 'Oh if she wants to go there so let it be'. No-one in her family has been educated beyond grade 12 . There are five siblings to support. Her parents are divorced-her stepmother is unemployed, and her father does house painting when he can get jobs. After she went to live with her father (she does not get on with her mother) she had a long journey to school each day but felt it was worth it. The resources at the school were limited and her peers did not work hard. For example, they refused to stay after school for study periods but Thabile commented that, 'this thing is not going to help learners'. For herself she worked hard and chose business subjects because she did not want to do science. Her parents 'never intervened much' including in her decision to go to university although they did not stand in her way: 'Everything that I make I don't have parental support, so whatever I decide to do, I do'. She had some support from teachers in that they support the 'clever' children and she had an accounting teacher who was 'very inspiring'. There was limited contact with universities who did not come to the school, although one student would be selected to go to an open day, usually someone doing maths and accounting. These students would keep the information to themselves and 'not share'. Thus, Thabile had to deal with the university application process on her own. She applied at CUT, which accepted her for auditing but then Thabile found she had been awarded a government bursary to study at UFS where she had applied to do Education with Accounting as her major, so she chose this. She is 'thrilled' to be at university.

Aphiwe attended a Q1 school in Thaba'Nchu, a poor area about an hour's drive from the UFS main campus. Her single mother, who works in a creche, chose the school based on its reputation. Aphiwe's brother, who did not complete grade 12 , works in a bakery. Her community struggles with unemployment, crime and teenage pregnancies so that there is a 'circle of poverty' because uneducated parents do not see the value of education and do not help their children 'to make good decisions'. But Aphiwe's mother encouraged her to study, to read, and she checked that homework had been done. The school had few resources and no access to computers, but teachers seemed to have tried by offering extra classes and holiday camps for matric students. On the other hand, they did not encourage student like Aphiwe who were not good at maths and had chosen maths lit- 
eracy. According to Aphiwe teachers told them that they would fail and 'not make it in life'. Aphiwe did not expect to go to university and only applied after she received the qualifying grade 12 pass. There was no help in applying from her school where teachers 'didn't even give any advice so I made my own choice'. Her teachers were also not demanding about assignments being done on time so when she submitted her application to study social work late she did not think this would be a problem. Thus, she did not get into social work and has ended up doing psychology but is satisfied. Aphiwe has a government loan, without this she could not go to university, as her mother had only managed to save enough for the initial registration fee. The loan covers fees, food and book, while her mother helps with the cost of the bus to get to campus from her home. She sees university as a way to make her mother proud and to help change people's lives after she graduates.

\subsection{How General Conversion Factors Shape Each Person's Capabilities}

Across the three students the general conversion factors of: government policy to widen access for black students; gender generally favouring girls; economic context and social class intersecting with race; family educational history; and school quality work out as each student's personal set of conversion factors. Being low income is a setback in making choices but not insuperable, but discouraging teachers do not help. Nonetheless, economic factors make a considerable difference, whether in the family or via government funding support. Undoubtedly being at a Q5 school is important in having more choices but this is offset by the determination on the part of Aphiwe and Thabile to get into university once they make the decision. All three students demonstrate agency and self-efficacy, and have reason to value this, but all three act under conditions not entirely of their own choosing. Palesa's goals are more clearly formulated, whereas for Aphiwe and Thabile they are more serendipitous. Preference formation mechanisms surprisingly do not necessarily generate downward adapted preferences-all three are aiming for the best they can achieve.

Palesa, Aphiwe and Thabile-from different starting points-seem set on social mobility pathways. For Palesa from the daughter of a primary school teacher to a lawyer, for Thabile the daughter of a house painter with grade 12 to a high school teacher, and Aphiwe the daughter of a creche worker to a degree but in this case with less clear career prospects as she cannot be a social worker. By evaluating their capabilities, the variations, and the conditions for capability formation and choices which lead to access, we can shift the axis of analysis to interrogating the conversion factors that enable individuals to make decisions about their lives. Self-efficacy can be considered a key educational good or internal capability for university access but needs to be combined with supportive external economic conditions for this to become a combined capability. All three students value the capability for social mobility and being able to improve the situation of their families or getting support from teachers who believe in them so good relationships clearly matter too. The internal capability of hard work and the value of academic achievement is strong in all three, despite variations in school quality, family support, and in their academic preparedness for university.

Across all the interview data there is a pattern of students who go to fees-free Q1-3 schools mostly choosing the school themselves, more rarely a grandmother or mother will make the choice if they know that a particular school has a good reputation. In some but not all cases mothers and grandmothers are influential in making decisions about education by encouraging hard work. Nonetheless, low income township pupils had to rely on their own resources in choosing their grade 12 subjects (this is done at the end of grade 9), or having the school make the choice for them. There were experiences of unemployment in these families and varying levels of parental interest in their schooling. Overall, low income students experienced little support from schools, who were aiming just to get students through grade 12 , or from parents unfamiliar with higher education, in applying for university or funding. Where teachers were encouraging it was only of the 'clever' children. In some cases of Q4 students parental support came only after they had got into university so that only once the realised aspiration became 'real' was it supported by the home. While there was information about university available at Q4 schools, it was the Q5 schools in which the assumption of proceeding to university was most strongly embedded. This was complemented by family expectations that going to university was non-negotiable, or that 'everyone in the family knows that university is the next journey after grade 12 '. There was support and knowledge available in families and at the school, while the schools also instilled the need for hard work and provided considerable support for university applications. These were also the schools visited by universities looking to recruit the best students.

Only for some students then is there a virtuous trilogy of school-family-university enabling wider personal options in the light of general conversion factors. We see this working most successfully for Palesa in being able to operationalize her combined capabilities, while the way her school prepared her for university study means that she ought to be able to iteratively realize her combined capabilities to succeed at university. But it is also clear that students do not have equality in substantive freedoms (in Sen's terms) to make choices about who they want to be and to do. Just looking at three lives we can see that not all three girls are in the position to make the same kind of choices and to develop their capabilities and functionings. This difference persists into university study based on what students told us about their first months of study, where some were well-prepared and others not at all. 


\section{Concluding Thoughts}

In South Africa, as elsewhere, choosing higher education, choosing a university and choosing a programme of study are not simply personal decisions but sit at the intersection of the person, her schooling, her family, university actions (such as school visits), government policy and social structures. How these multiple factors intersect will either give the green light for genuine choice in access (achieving a place of choice at the university of choice), or an amber light for constrained choices. At the same time, the capability approach allows us to see human agents with the power to act, even where social arrangements get in the way. Thabile and Aphiwe show remarkable agency and navigational skills in overcoming general conversion factors to construct personal options.

Policy through dialogue and consultation might aim at a 'general' capability set (to include for example, selfefficacy, knowledge and good relationships) which would be valuable for any student, whether or not they directly value the capability. A general set could be a guide both to evaluating whether people have the capabilities to access university, and to making changes to expand capabilities. While universities may not be able to compensate for poor schooling they can visit low income schools, explain access pathways, encourage aspirations, and help with applications, acknowledging the agency and internal self-efficacy capability that many students in these schools have, enabling this as a combined capability for a social mobility pathway.

However, as things stand now, when we look across the life chances of low income South African youth who do not have access to better schools or a significant 'other' providing support and encouragement we are some way off the kind of equitable access that does not allow circumstances to limit opportunities. Achieving a place and being satisfied with that achievement (or functioning) choice are affected by multiple factors in each person's life, including uneven capability sets shaped by resources, social conversion factors, preference formation and individual talents and qualities. At the same time, we should not lose sight of possibility summed up by Thabile who told us:

Coming to university is like putting one step into your future, into a brighter future....Others have a brighter future even if they don't come to university. But some of us are not born with that thing to just be successful, you have to get an education before you become successful.

\section{Acknowledgements}

This research has been supported by a grant from the NRF, grant number 86450 . My thanks to the postdoctoral researchers who were part of the Access Project.

\section{Conflict of Interests}

The author declares no conflict of interests.

\section{References}

Bandura, A. (1994). Self-efficacy. In V. S. Ramachaudran (Ed.), Encyclopedia of human behaviour (vol 4.; pp. 71-81). New York, NY: Academic Press.

Council on Higher Education. (2016). VitalStats 2016. Pretoria: $\mathrm{CHE}$.

DeJaeghere, J., \& Baxter, A. (2017). Entrepreneurship education for youth in sub-Saharan Africa: A capabilities approach as an alternative framework to neoliberalism's individualizing risks. Progress in Development Studies, 14(1), 61-76.

Makgetla, N. (2018, January 16). Funding can be found to implement free education plan. Business Day.

Nussbaum, M. (2000). Women and human development: The capabilities approach. Cambridge: Cambridge University Press.

Robeyns, I. (2017). Wellbeing, freedom and social justice: The capability approach re-examined. Cambridge: Open Book Publishers.

Sen, A. (2009). The idea of justice. Oxford: Oxford University Press.

Southall, R. (2016). The new black middle class in South Africa. Sunnyside: Jacana.

Spaull, N. (2012). Education in SA: A tale of two systems. Politicsweb. Retrieved from www.politicsweb.co. za/news-and-analysis/education-in-sa-a-tale-of-twosystems

Spiegler, T. (2018). Resources and requirements of educational upward mobility. British Journal of Sociology of Education. Advanced online publication. https://doi.org/10.1080/01425692.2018.1425131

Sulla, V., \& Zikhali, P. (2018). Overcoming poverty and inequality in South Africa: An assessment of drivers, constraints and opportunities (English). Washington, DC: World Bank Group. Retrieved from documents.worldbank.org/curated/en/5304815217 35906534/Overcoming-Poverty-and-Inequality-inSouth-Africa-An-Assessment-of-Drivers-Constraintsand-Opportunities

Van Broekhuizen, H., Van Der Berg, S., \& Hofmeyr, H. (2016). Higher education access and outcomes for the 2008 national grade 12 cohort (Stellenbosch Working Papers 16/6). Stellenbosch: University of Stellenbosch.

Van Broekhuizen, H., \& Spaull, N. (2017). The 'Martha effect': The compounding female advantage in South African higher education (Stellenbosch Economic Working Papers WP14/2017). Retrieved from www. ekon.sun.ac.za/wpapers/2017/wp142017

Walker, M. (2018). A multi-dimensional approach to access. In P. Ashwin \& J. Case (Eds.), Pathways to the public good: Access, experiences and outcomes of South African undergraduate education. Stellenbosch: African Minds. 


\section{About the Author}

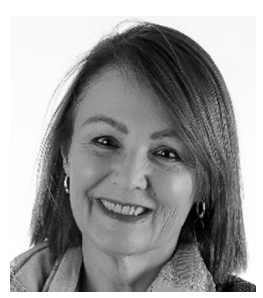

Melanie Walker is South African Research Chair in Higher Education \& Human Development at the University of the Free State. She is an elected fellow of the Academy of Science of South Africa and the Human Development and Capability Association. She supervises graduate students and does research on social justice, development ethics, capabilities, and international education, all with a specific focus on higher education. 